\title{
Accuracy of Olsen $P$ to assess plant $P$ uptake in relation to soil properties and $P$ forms
}

\author{
Ramiro Recena $^{1} \cdot$ José Torrent $^{2} \cdot$ María Carmen del Campillo $^{2} \cdot$ Antonio Delgado $^{1}$
}

Accepted: 22 July 2015 /Published online: 7 September 2015

(C) INRA and Springer-Verlag France 2015

\begin{abstract}
Efficient use of phosphorus (P) by plants in agriculture relies on accurate estimation of the phytoavailable soil P. However, poor relationships are frequently observed between $\mathrm{P}$ availability indices, such as Olsen $\mathrm{P}$, and $\mathrm{P}$ uptake by plants. We therefore studied which soil properties modify the accuracy of Olsen $\mathrm{P}$ as a $\mathrm{P}$ availability index. We conducted a soil $\mathrm{P}$ depletion experiment in pots with 17 soils. Two samples differing widely in Olsen $\mathrm{P}$ were used for each soil and named "low-P" and "high-P." Soil was mixed with siliceous sand to achieve $1 \mathrm{mg}$ of Olsen $\mathrm{P}$ per pot, so that the ratio of non-readily available $\mathrm{P}$, either inorganic $\mathrm{P}$ or organic $\mathrm{P}$, to Olsen $\mathrm{P}$ in the pot was higher for low-P than for high-P samples. Results show that, in high-P samples, $\mathrm{P}$ uptake by cucumber is positively correlated with the affinity of the soil solid phase for $\mathrm{P}$, with $R^{2}$ of 0.76 . In high-P samples, $\mathrm{P}$ uptake by cucumber is positively correlated with total $\mathrm{P}$ adsorption capacity as estimated by $\mathrm{Fe}$ in the form of Fe oxides, with $R^{2}=$ 0.56 . $\mathrm{P}$ uptake is positively correlated with the inorganic $\mathrm{P}$ released by $\mathrm{NaOH}$ and citrate-bicarbonate in low-P samples, with $R^{2}$ of 0.52 . In low-P samples, total organic $\mathrm{P}$ and phosphatase activity in the rhizosphere explained $37 \%$ of plant $\mathrm{P}$ uptake. In low-P samples, phosphatase activity and $\mathrm{pH}$ explained $50 \%$ of plant $\mathrm{P}$ uptake. These findings reveal that organic $\mathrm{P}$ forms and hydrolytic activity by roots are explaining $\mathrm{P}$ availability to plants. Whereas physico-chemical processes
\end{abstract}

Antonio Delgado

adelgado@us.es

1 Departamento de Ciencias Agroforestales, ETSIA, Universidad de Sevilla, Ctra. Utrera km 1, 41013 Sevilla, Spain

2 Departamento de Agronomía, Universidad de Córdoba, Edificio C4, Campus de Rabanales, 14071 Córdoba, Spain controlling inorganic $\mathrm{P}$ dynamics play a major role for low organic $\mathrm{P} /$ Olsen $\mathrm{P}$ ratios.

Keywords Olsen P · Available P · Availability index · Affinity for $\mathrm{P} \cdot$ Organic $\mathrm{P}$

\section{Introduction}

Phosphorus is a non-renewable and strategic resource that is essential for life - and thus for agriculture. Limited known reserves and increased demand to match rising food needs of a growing World population make feasible future scarcity and rising prices of this commodity (Cordell et al. 2009; Keyzer 2010; Van Vuuren et al. 2010; Ryan et al. 2012). This future $P$ scarcity is emerging as one of the key global environmental challenges (Cordell and Neset 2014).

Society depends on inorganic P, but its use is inefficient (Withers et al. 2014). More than $80 \%$ of mined phosphate rock is used in fertilizer industry (Cordell et al. 2009; Ryan et al. 2012), and it is well known that only a fraction of applied P remains available to crops (Delgado et al. 2002; Delgado and Scalenghe 2008). More efficient use of $P$ in agriculture requires more accurate $\mathrm{P}$ fertilizer recommendations, which should rely on accurate estimation of the phytoavailable $\mathrm{P}$ in soil. This estimation is based on chemical extractions as a proxy for the P potentially releasable from the solid phase and thus available to plants (Kpomblekou and Tabatabai 1997; Delgado et al. 2010). Depending on soil properties and dominant $P$ forms, different relationships between extractable and plant-available P can be expected (Mallarino 1997; Delgado and Torrent 1997; 2001), thus making it impossible to adopt a universal method to assess available $\mathrm{P}$ in soil (Delgado and Scalenghe 2008; Tandy et al. 2011). This justifies that, only in Europe, $16 \mathrm{P}$ extraction methods to assess 
plant-available P have been proposed (Neyroud and Lischer 2003; Tóth et al. 2014).

The primary target of any "available $\mathrm{P}$ index" is to identify responsive sites to $P$ fertilization via defining a precise threshold value above which the probability of a crop to respond to the soil application of a P fertilizer is low (Neyroud and Lischer 2003; Tandy et al. 2011). Different factors can affect the relationship between $\mathrm{P}$ in solid and liquid phases thus affecting the accuracy of estimated threshold levels for each index even in groups of soils of homogeneous properties (Delgado et al. 2010). It is generally accepted that the P buffer capacity (PBC), which is the soil solution resistance to a change in $\mathrm{P}$ concentration, is a crucial factor affecting equilibrium between solid and liquid phases (Holford 1980; Ehlert et al. 2003; Celardin 2003). Factors such as soil P status (Barrow and Debnath 2014), the affinity of sorbent surfaces for $\mathrm{P}$, or the proportion of exchangeable cations can also affect this equilibrium (Delgado et al. 2010). All these factors contribute to explain the poor relationship frequently observed between a widely used index such as Olsen P (bicarbonateextractable P; Olsen et al. 1954) and P uptake by plants (Kulhánek et al. 2007), even in soils with similar properties (Delgado et al. 2010). To overcome this limitation, other methods theoretically sensitive to soil PBC such as the use of near infinite sinks (i.e., Fe oxides, Delgado and Torrent 1997; or resins, Delgado et al. 2010) or to the study of diffusive gradients in thin films (DGT; Mason et al. 2010; Tandy et al. 2011) have been proposed. Also, corrections of traditional indexes based on single soil properties could lead to more accurate assessing of available soil $\mathrm{P}$ thus to more accurate $\mathrm{P}$ fertilization recommendations (Delgado et al. 2010).

A better understanding of how a given available $P$ index is related to the plant-available $\mathrm{P}$ in soil and how this relationship is affected by soil properties will provide new insight into the correct use of Olsen's and other P availability indices by defining more precise threshold values. In this regard, the aim of this work was to identify the factors that affect the accuracy of Olsen P, a widely used test in many areas of the world. To this end, the relationship between plant $\mathrm{P}$ uptake and Olsen $\mathrm{P}$ was assessed for a widely ranging group of soils from Mediterranean areas in order to assess how this relation can be affected by soil properties and, particularly, by the soil $\mathrm{P}$ status.

\section{Material and methods}

\subsection{Soils}

A soil $\mathrm{P}$ depletion experiment was conducted in a growth chamber with 17 agricultural soils that encompassed the most representative soil types of the Mediterranean part of Spain. According to Soil Taxonomy (Soil Survey Staff 2010), the soils were classed as Mollisols, Entisols, Inceptisols, Alfisols, and Vertisols and most of them were in the typical rainfed crop rotation in Spain, i.e., wheat-sunflower. Soil samples were taken at least 1 year after P fertilizer had been applied to soil and, in rainfed rotations, mostly after sunflower (i.e., 2 years after the last $\mathrm{P}$ application). A set of samples of the surface layer $(0-20 \mathrm{~cm})$ in each location where a homogeneous soil was identified were taken in order to obtain a collection of samples widely ranging in Olsen P. The samples with the two extreme values were selected for this study and named "low-P" and "high-P" samples according to their P status. Soil properties, including $\mathrm{Fe}$ in $\mathrm{Fe}$ oxides, were checked to ensure that they differed by less than $5 \%$ between "high-P" and "low-P" samples.

Soil samples $(5-7 \mathrm{~kg})$ from each soil were homogenized, dried, and ground to $<6 \mathrm{~mm}$. A representative subsample was taken for physical and chemical analysis. This subsample was ground to pass a 2-mm sieve. Particle size analyses were carried out using the densimeter method (Gee and Bauder 1986), organic matter (SOM) was determined by dichromate oxidation (Walkley and Black 1934), and the cation exchange capacity (CEC) by using $1 \mathrm{M} \mathrm{NH}_{4} \mathrm{OAc}$ buffered at $\mathrm{pH} 7$ (Sumner and Miller 1996). The total $\mathrm{CaCO}_{3}$ equivalent (CCE) was determined by the calcimeter method, and $\mathrm{pH}$ was measured in water at a soil:extractant ratio of 1:2.5. Olsen P was determined according to Olsen et al. (1954), replacing filtration through active carbon by centrifugation at $1000 \mathrm{~g}$ during $10 \mathrm{~min}$. Molybdate-reactive P (Murphy and Riley 1962) and total P after persulphate digestion in autoclave (Díaz-Espejo et al. 1999) were determined in the supernatant.

\subsection{Experimental design}

An experiment was performed in 350-mL cylindrical polystyrene pots $(5.5 \mathrm{~cm}$ diameter, $15 \mathrm{~cm}$ high) filled with a mixture of washed siliceous sand and soil. The amount of soil in the pot was that which contained $1 \mathrm{mg}$ of Olsen $\mathrm{P}$ and ranged from 21 to $109 \mathrm{~g}$ for high-P samples and from 100 to 170 for low-P samples. Concentration of Olsen $\mathrm{P}$ and Fe oxides in the washed sand was negligible. The amount of Olsen $\mathrm{P}$ in each pot was intended to provide an amount of available $\mathrm{P}$ in each pot similar to the amount expected to be extracted by crops during the experiment, in such a way that some symptoms of $\mathrm{P}$ deficiency could be expected at the end of the experiment. In each pot, a cucumber plant (Cucumis sativus L. cv Serena; hybrid F1; Nunhems, Almería, Spain) was grown for 50 days. Previously, seeds were germinated on alveolated trays containing perlite as substrate and transplanted to the pots after 16 days.

Plants were grown under controlled conditions in a growth chamber with 14-h photoperiod, a relative humidity of 45 (day period) and $60 \%$ (night period), and an active photosynthetic 
radiation of $22 \mathrm{~W} \mathrm{~m}^{-2}$. The experimental design was a randomized complete block with two treatments (high-P and low$\mathrm{P}$ samples) and two replications. Pots were irrigated with $20 \mathrm{~mL}$ of P-free Hoagland-type nutrient solution at $\mathrm{pH}$ 66.5 four times a week, enough to result in a modest drainage, and with the same volume of deionized water once a week to prevent salt accumulation in soil. The composition of the solution applied was (all concentrations in $\mathrm{mmol} \mathrm{L}^{-1}$ ) $\mathrm{MgSO}_{4}$ (2), $\mathrm{Ca}\left(\mathrm{NO}_{3}\right)_{2}$ (5), $\mathrm{KNO}_{3}(5), \mathrm{KH}_{2} \mathrm{PO}_{4}(1), \mathrm{KCl}(0.05)$, $\mathrm{H}_{3} \mathrm{BO}_{3}(0.009), \mathrm{MnCl}_{2}(0.0023), \mathrm{CuSO}_{4}(0.0005), \mathrm{ZnSO}_{4}$ (0.002), and $\mathrm{H}_{2} \mathrm{MoO}_{4}(0.0005)$.

\subsection{Study of $P$ forms and $P$ sorption capacity in soils}

Phosphorus forms in soil before the experiment were studied by means of an operational method based on sequential chemical fractionation, which provides information about the $\mathrm{P}$ fractions in the soil solid phase with different ability to be released to the soil solution. The sequential fractionation scheme used was that of Ruiz et al. (1997) modified according to Saavedra et al. (2007), which includes two additional steps to extract "hot" alkali-extractable organic P and residual organic P. Extraction steps include:

(i) $0.1 \mathrm{M} \mathrm{NaOH}+1 \mathrm{M} \mathrm{NaCl}(\mathrm{NaOH}$ fraction), which releases adsorbed $\mathrm{P}$, $\mathrm{P}$ precipitated as $\mathrm{Fe}-$ and $\mathrm{Al}$-phosphates, and $\mathrm{P}$ bound by $\mathrm{Fe}$ and $\mathrm{Al}$ organic complexes;

(ii) $0.27 \mathrm{M} \mathrm{Na}$ citrate $+0.11 \mathrm{M} \mathrm{NaHCO}_{3}$ (citrate-bicarbonate, $\mathrm{cb}$ fraction), which extracts remaining adsorbed $\mathrm{P}$ and soluble $\mathrm{Ca}$ phosphates, partly precipitated or adsorbed on calcite after $\mathrm{NaOH}$ extraction in calcareous soils;

(iii) $0.25 \mathrm{M} \mathrm{Na}$-citrate at $\mathrm{pH} 6$, and

(iv) $0.2 \mathrm{M} \mathrm{Na}$-citrate $\mathrm{pH} 6$, being the combination of $\mathrm{P}$ extracted by these two consecutive extractions (citrate, $\mathrm{c}$ fraction) ascribed to $\mathrm{P}$ precipitated as pedogenic $\mathrm{Ca}$ phosphates not dissolved in the previous step (mostly hydroxyapatite);

(v) $0.2 \mathrm{M} \mathrm{Na}$ citrate $+0.05 \mathrm{M}$ ascorbate at $\mathrm{pH} 6$ (citrateascorbate, "mild reductant soluble P", ca fraction), which releases $\mathrm{P}$ occluded in poorly crystalline $\mathrm{Fe}$ oxides mainly;

(vi) $0.27 \mathrm{M} \mathrm{Na}$ citrate $+0.11 \mathrm{M} \mathrm{NaHCO}_{3}+2 \% \mathrm{Na}$ dithionite (citrate-bicarbonate-dithionite, "reductant soluble P", cbd fraction), which releases $\mathrm{P}$ occluded in crystalline Fe oxides;

(vii) $1 \mathrm{M} \mathrm{NaOAc}$ buffered at $\mathrm{pH} 4$ (OAc), which releases residual pedogenic $\mathrm{Ca}$ phosphates previously not dissolved by citrate;

(viii) $1 \mathrm{M} \mathrm{HCl}$, which dissolves most lithogenic apatite;

(ix) $2 \mathrm{M} \mathrm{NaOH}$, which releases alkali extractable organic $\mathrm{P}$; and

(x) $0.5 \mathrm{M} \mathrm{H}_{2} \mathrm{SO}_{4}+0.37 \mathrm{M} \mathrm{K}_{2} \mathrm{~S}_{2} \mathrm{O}_{8}$ for $1 \mathrm{~h}$ which releases residual organic $\mathrm{P}$.
All extractions were performed in triplicate using polyethylene flasks at $25^{\circ} \mathrm{C}$, except the two last steps, which were performed at $90^{\circ} \mathrm{C}$ ("hot" alkali extractable) and $130^{\circ} \mathrm{C}$ in an autoclave. After centrifugation at $1000 \mathrm{~g}$ during $10 \mathrm{~min}$, all extracts were analyzed for molybdate-reactive $\mathrm{P}$ (Murphy and Riley 1962) and total P following sulphuric-persulphate digestion (Díaz-Espejo et al. 1999), except for "hot NaOH-P," which was analyzed for total P only, and the last step, where only molybdate-reactive $\mathrm{P}$ was determined. Differences between molybdate-reactive $\mathrm{P}$ and total $\mathrm{P}$ in the extracts can be assigned mainly to organic P (Golterman et al. 1998), so a distinction could be made between organic and inorganic (molybdate-reactive, MRP) P in each fractionation step. The $\mathrm{P}$ extracted in the last two steps was taken as "recalcitrant" organic P. In the citrate-ascorbate and citrate-bicarbonatedithionite extracts from steps $\mathrm{v}$ and vi, Fe was also determined by atomic absorption spectrometry $\left(\mathrm{Fe}_{\mathrm{ca}}\right.$ and $\mathrm{Fe}_{\mathrm{d}}$, respectively). The citrate-ascorbate extractable Fe was ascribed to poorly crystalline Fe oxides and the citrate-bicarbonate-dithionite extractable to crystalline Fe oxides. Inorganic $\mathrm{P}$ in soils was estimated as the sum of molybdate-reactive $\mathrm{P}$ in each fraction (except fractions ix and $\mathrm{x}$, ascribed to recalcitrant organic $\mathrm{P}$ ), and organic $\mathrm{P}$ as the sum of organic $\mathrm{P}$ in each fraction (considering as organic, total $\mathrm{P}$ in the "hot $\mathrm{NaOH}$ " extraction, and MRP in the last step).

Sorption capacity of soils was assessed by performing sorption curves at 6 days according to the method of Fox and Kamprath (1970). Sorption curves were fitted to the Freundlich equation:

$Y=A X^{1 / b}$

Where $Y$ is the sorbed $\mathrm{P}$ in soil, $X$ is the remaining $\mathrm{P}$ concentration in solution, and $b$ can be considered the affinity factor, in such a way that higher values correspond to higher affinity of soil particles for P. The PBC was estimated as the slope of the sorption curve at equilibrium concentration $\left(\mathrm{BC}_{\mathrm{e}}\right)$ and at $0.2\left(\mathrm{BC}_{0.2}\right)$ and $1 \mathrm{mg} \mathrm{L}^{-1}\left(\mathrm{BC}_{1}\right)$.

\subsection{Plant and soil analysis at the end of the experiment}

After cropping, plants were harvested and shoots and roots separated. Plant material was washed and then dried in a forced-air oven until constant weight at $65{ }^{\circ} \mathrm{C}$ for at least $48 \mathrm{~h}$. After determining dry matter (DM), plant tissues were ground to pass a 1-mm screen and analyzed for P. To this end, plant material was mineralized by igniting a portion of $0.25 \mathrm{~g}$ in porcelain crucibles in a furnace at $550{ }^{\circ} \mathrm{C}$ during $8 \mathrm{~h}$. After that, $10 \mathrm{~mL}$ of $1 \mathrm{M} \mathrm{HCl}$ was used to dissolve ashes, heated at $100{ }^{\circ} \mathrm{C}$ for $15 \mathrm{~min}$, and $\mathrm{P}$ determined by the colorimetric method of Murphy and Riley (1962) in the resulting digest. Certified plant material (1547 Peach Leaves, Sugerlabor, S.A., National Institute of Standard and Technology, Gaithersburg) 
was also analyzed to assess complete recovery of $\mathrm{P}$ by this procedure, confirming that the recovery of $\mathrm{P}$ in this certified material was always $90-110 \%$.

After harvest, alkaline phosphatase activity in rhizosphere soil was determined according to the method of Tabatabai (1994) as the amount of $p$-nitrophenol released from $p$-nitrophenol phosphate at $37{ }^{\circ} \mathrm{C}$ and at $\mathrm{pH}$ of 9. Until phosphatase determination, the soil was stored at $5{ }^{\circ} \mathrm{C}$ for no more than 10 days.

\subsection{Statistical analysis}

The effect of soil and treatment (high-P vs low-P) on different variables was assessed by means of a two-way ANOVA using the general linear model procedure in Statgraphics Plus 5.1 (StatPoint, 2000). Previously, data were checked for normal distribution and homoscedasticity by using the KolmogorovSmirnov test and Levenne test, respectively, as implemented with the previous software. Differences between means were assessed by the LSD test $(P<0.05)$ Regressions and correlations were also calculated using the same software; influential points in regressions were assessed by the Leverage test.

\section{Results and discussion}

Soils ranged widely in properties, particularly in carbonates and $\mathrm{Fe}$ oxides, which are relevant properties affecting $\mathrm{P}$ dynamics in soil. Clay content ranged from 48 to $640 \mathrm{~g} \mathrm{~kg}^{-1}$, organic matter (SOM) between 5.5 and $20 \mathrm{~g} \mathrm{~kg}^{-1}$, calcium carbonate equivalent (CCE) between 34 and $723 \mathrm{~g} \mathrm{~kg}^{-1}$, citrate-ascorbate- and citrate-bicarbonate-dithionite extractable Fe according to Ruiz et al. (1997) between 0.17-2.44 and $2.2-21 \mathrm{~g} \mathrm{~kg}^{-1}$, respectively, $\mathrm{pH}$ from 6.5 to 8.3 , and cation exchange capacity from 9.1 to $52.3 \mathrm{cmol}(+) \mathrm{kg}^{-1}$.

Phosphorus enrichment by fertilization only increased inorganic $\mathrm{P}$ as revealed by the significant difference between high- and low-P samples (Table 1). Only inorganic $\mathrm{P}$ in the $\mathrm{cb}$ and $\mathrm{ca}$ fractions differed significantly (Table 1 ). From the excess of $200 \mathrm{mg} \mathrm{P} \mathrm{kg}^{-1}$ in the sum of inorganic $\mathrm{P}$ fractions of high-P relative to low-P samples, only $63 \mathrm{mg} \mathrm{kg}^{-1}$ were recovered in the fractions corresponding to the most readily desorbable $\mathrm{P}\left(\mathrm{NaOH}+\mathrm{cb}\right.$; Table 2) and only $15 \mathrm{mg} \mathrm{kg}^{-1}$ by bicarbonate (Olsen's method). According to the ratio of total plant-available P to Olsen P defined by Delgado and Torrent (1997) in similar soils (total available P was roughly equivalent to 1.5 times Olsen P), this means that approximately a $10 \%$ of applied P remained readily available to plants. It should be noted that non-significant differences were observed in total organic $\mathrm{P}$ or organic fractions between highand low-P samples (Table 1). Organic P, estimated as the sum of organic $\mathrm{P}$ fractions, accounted on average for $50 \%$ of total $\mathrm{P}$ estimated as sum of inorganic and organic $\mathrm{P}$ fractions in
low-P samples (Table 1). This means that, in spite of being poorly understood $\mathrm{P}$ forms in these soils, they can be dominant (Saavedra and Delgado 2005; Delgado and Scalenghe 2008). On average, the ratio of organic $P$ to Olsen $P$ was 2.4 times higher in pots with low- than in pots with high-P samples, meanwhile the ratio of inorganic $\mathrm{P}$ to Olsen $\mathrm{P}$ was 1.7 times higher. Also, total and organic $\mathrm{P}$ in pots was roughly twice in low- (83 and $42 \mathrm{mg} \mathrm{kg}^{-1}$, respectively) than in high-P samples (41 and $19 \mathrm{mg} \mathrm{kg}^{-1}$, respectively). Thus, the ratio of non-readily phytoavailable $\mathrm{P}$ to that assumed to be available was greater in pots with low- than in those with high-P samples. Significant differences were neither observed in sorption parameters nor in PBC estimates (Table 2).

Phosphorus concentration in shoots and roots did not differ significantly between high- and low-P samples. Dry matter yield in shoots was significantly greater in high- than in low$P$ samples (Table 2). In spite of the same amount of Olsen $\mathrm{P}$ in the pots ( $1 \mathrm{mg}$ per pot), $\mathrm{P}$ extraction by plants ranged from 1.05 to $3.33 \mathrm{mg} \mathrm{pot}^{-1}\left(\mathrm{mg} \mathrm{plant}^{-1}\right)$ in high-P samples and from 1.02 to $2.19 \mathrm{mg} \mathrm{pot}^{-1}$ in low-P samples, and $\mathrm{P}$ extraction by plants differed between samples with different $\mathrm{P}$ status, it being on average $11 \%$ greater in high- (mean $1.65 \mathrm{mg} \mathrm{pot}^{-1}$ ) than in low-P samples (mean $1.49 \mathrm{mg} \mathrm{pot}^{-1}$; Table 2). These evidences reveal that the actual amount of available $P$ in pots was not accurately predicted by this soil $\mathrm{P}$ availability index. Previous evidences in a group of calcareous clayey soil with similar properties revealed that threshold values of Olsen $\mathrm{P}$ for fertilizer response ranged widely (from 2 to 15 ) revealing that this method was not a precise index for fertilizer recommendations (Delgado et al. 2010). This was also in agreement with results by Tandy et al. (2011) who did not observe significant relationship between Olsen $\mathrm{P}$ and $\mathrm{P}$ in plant in a group of soils ranging widely in $\mathrm{pH}$. On average, $\mathrm{P}$ extracted by plants accounted for the expected total available $\mathrm{P}$ in soil according to Delgado and Torrent (1997), which was 1.5 times Olsen P, thus explaining the evident $\mathrm{P}$ deficiency symptoms observed at the end of the experiment (Fig. 1). Thus, as expected, the experimental setup was efficient to deplete the total plant available $\mathrm{P}$ in soil.

Phosphorus uptake did not depend on the amount of $\mathrm{P}$ in soil that was potentially available to plants, i.e., the classical "quantity" factor-which basically relates to Olsen P (Sánchez-Alcalá et al. 2014). Only the affinity factor of the Freundlich equation $(b)$ was a significant explanatory variable for both high- and low-P samples (Fig. 2). This reveals, as expected, that factors affecting the equilibrium between inorganic $\mathrm{P}$ in the solid and liquid phases, such as soil affinity for $\mathrm{P}$, affect the uptake of $\mathrm{P}$ by plants much more that the amount of potentially desorbable $\mathrm{P}$ as estimated from chemical extraction. Affinity for $\mathrm{P}$ is known to be a crucial factor explaining the release P from the solid phase (e.g., to subsurface flow, McDowell et al. 2002). The relevance of affinity for $P$ affecting $\mathrm{P}$ availability to plants was also described by Delgado 
Table 1 Main inorganic and organic P fractions according to the fractionation scheme of Saavedra et al. (2007) and availability index according to Olsen et al. (1954) in the studied soils before crop experiment

\begin{tabular}{|c|c|c|c|c|c|c|c|c|c|c|c|}
\hline & & Olsen P & \multicolumn{8}{|c|}{ Inorganic fractions } & \multirow[t]{3}{*}{ Sum $\mathrm{IP}^{\mathrm{a}}$} \\
\hline & & & $\mathrm{NaOH}$ & $\mathrm{cb}^{\mathrm{a}}$ & $\mathrm{c}$ & $\mathrm{ca}^{\mathrm{a}}$ & cbd & OAc & $\mathrm{HCl}$ & & \\
\hline & & $\mathrm{mg} \mathrm{kg}^{-1}$ & & & & & & & & & \\
\hline \multirow[t]{2}{*}{ Low-P samples } & Mean \pm SD & $9 \pm 3$ & $13 \pm 21$ & $41 \pm 15$ & $102 \pm 94$ & $56 \pm 47.9$ & $47 \pm 17$ & $37 \pm 50$ & $25 \pm 13$ & & $369 \pm 135$ \\
\hline & Range & $5-16$ & $1-74$ & $17-68$ & $9-337$ & $13-179$ & $21-86$ & $3-190$ & $8-60$ & & $179-691$ \\
\hline \multirow[t]{5}{*}{ High-P samples } & Mean \pm SD & $24 \pm 10$ & $20 \pm 32$ & $97 \pm 69$ & $158 \pm 164$ & $107 \pm 178$ & $56 \pm 35$ & $53 \pm 66$ & $30 \pm 21$ & & $570 \pm 441$ \\
\hline & Range & $9-49$ & $1-100$ & $26-302$ & $12-684$ & 19-778 & $28-185$ & $4-262$ & $5-79$ & & $231-2220$ \\
\hline & & Olsen OP & \multicolumn{8}{|c|}{ Organic fractions } & Sum OP \\
\hline & & & $\mathrm{NaOH}$ & $\mathrm{cb}$ & $\mathrm{c}$ & $\mathrm{ca}$ & cbd & OAc & $\mathrm{HCl}$ & Recalcitrant OP & \\
\hline & & $\mathrm{mg} \mathrm{kg}^{-1}$ & & & & & & & & & \\
\hline \multirow[t]{2}{*}{ Low-P samples } & Mean \pm SD & $3 \pm 2$ & $21 \pm 12$ & $42 \pm 15$ & $78 \pm 32$ & $43 \pm 25$ & $30 \pm 13$ & $41 \pm 18$ & $19 \pm 5$ & $78 \pm 29$ & $352 \pm 90$ \\
\hline & Range & $0-8$ & $5-56$ & $21-77$ & $1-132$ & $1-114$ & $0-51$ & $24-107$ & $9-31$ & $32-137$ & $219-551$ \\
\hline \multirow[t]{2}{*}{ High-P samples } & Mean \pm SD & $2 \pm 2$ & $23 \pm 15$ & $41 \pm 18$ & $79 \pm 22$ & $61 \pm 84$ & $33 \pm 24$ & $54 \pm 50$ & $21 \pm 7$ & $80 \pm 24$ & $391 \pm 98$ \\
\hline & Range & $0-7$ & $10-68$ & $7-83$ & $40-112$ & $21-392$ & $0-70$ & $30-244$ & $9-33$ & $48-126$ & $290-728$ \\
\hline
\end{tabular}

$I P$ inorganic $\mathrm{P}$ (molybdate reactive), $O P$ organic $\mathrm{P}$; subindexes: $\mathrm{NaOH} \mathrm{NaOH}$ extractable, $c b$ citrate-bicarbonate, $c$ citrate, $c a$ citrate-ascorbate, $c b d$ citrate-bicarbonate-dithionite, $O A c$ acetate, Olsen $O P$, organic $\mathrm{P}$ in bicarbonate extracts according to Olsen et al. (1954), SD standard deviation

${ }^{a}$ Differences between low- and high-P samples were only significant for cb, ca, and sum of IP; $P=0.005, P=0.0166$, and $P=0.0141$, respectively

et al. (2010) using the Langmuir model in a group of soils with a narrow range of properties. In contrast, our results do not reveal a very clear effect of the $\mathrm{PBC}$ as estimated from the sorption curves: only a slight negative correlation $(r=-0.48$; $P<0.05$ ) between plant $\mathrm{P}$ uptake and $\mathrm{PBC}$ at the equilibrium concentration in high-P samples was found. This lack of relevant explicative value of $\mathrm{PBC}$ contradicts previous works (Ehlert et al. 2003; Celardin 2003) which highlighted the relevance of this factor for the availability of $\mathrm{P}$ to plants. Since our experiment likely promoted a relevant starvation of available $\mathrm{P}$ in soil disposed in pots, with a significant change in the amount of sorbed $\mathrm{P}$ in equilibrium with the soil solution, a factor related to this equilibrium across a wide range of $\mathrm{P}$ concentrations in solution, such as the affinity factor $(b)$, was

Table 2 Sorption curve parameters, estimated buffer capacity (BC) at different $\mathrm{P}$ concentration in the soil solution, dry mass (DM) yield, $\mathrm{P}$ concentration in shoot and roots, and $\mathrm{P}$ uptake by plants from pots and likely to explain P phytoavailability better than PBC at a given solution $\mathrm{P}$ concentration.

The affinity factor $(b)$ depends on the nature of the $\mathrm{P}$ sorbing surfaces in soil. Crystalline Fe oxides show a higher affinity for $\mathrm{P}$ (higher $b$ values) than their poorly crystalline counterparts (Colombo et al. 1994; Guzman et al. 1994), as revealed in our high-P samples by the significant negative correlation between $\mathrm{Fe}_{\mathrm{ca}} / \mathrm{Fe}_{\mathrm{d}}$ and $b(r=-0.63 ; P<0.01)$. This correlation contributes to explain the positive correlation between $\mathrm{Fe}_{\mathrm{ca}} / \mathrm{Fe}_{\mathrm{d}}$ and plant $\mathrm{P}$ uptake $(r=0.51 ; P<0.05)$ for these samples. Not only the nature but also the amount of sorbents seems to affect $\mathrm{P}$ uptake as concluded from the correlation between $\mathrm{P}$ uptake and $\mathrm{Fe}_{\mathrm{ca}}+\mathrm{Fe}_{\mathrm{d}}$ in high-P samples (Fig. 2). This can be partially explained by the negative

alkaline phosphatase activity in rhizosphere with a mixture of siliceous sand and soil to encompass $1 \mathrm{mg}$ of Olsen P supplied per plant

\begin{tabular}{|c|c|c|c|c|c|c|c|c|c|c|c|c|}
\hline & & A & $\mathrm{b}$ & $\mathrm{BC}_{\mathrm{e}}$ & $\mathrm{BC}_{0.2}$ & $\mathrm{BC}_{1}$ & $\begin{array}{l}\text { DM } \\
\text { shoots }^{\mathrm{a}} \\
\text { g plant }^{-1}\end{array}$ & $\begin{array}{l}\text { DM } \\
\text { roots }\end{array}$ & $\begin{array}{l}\text { P concentration } \\
\text { shoots } \\
\mathrm{mg} \mathrm{kg}^{-1}\end{array}$ & $\begin{array}{l}\mathrm{P} \text { concentration } \\
\text { roots }\end{array}$ & $\begin{array}{l}\text { P uptake }{ }^{\mathrm{b}} \\
\text { mg } \\
\text { plant }^{-1}\end{array}$ & $\begin{array}{l}\text { Phosphatase }^{\mathrm{c}} \\
\mathrm{mg} \mathrm{PNP} \\
\mathrm{kg}^{-1} \mathrm{~h}^{-1}\end{array}$ \\
\hline \multirow{2}{*}{$\begin{array}{l}\text { Low-P } \\
\text { samples }\end{array}$} & Mean $\pm \mathrm{SD}$ & $72 \pm 32.3$ & $2.2 \pm 0.31$ & $348 \pm 413$ & $78 \pm 35$ & $32 \pm 14$ & $1.45 \pm 0.31$ & $0.22 \pm 0.09$ & $0.97 \pm 0.14$ & $1.31 \pm 0.30$ & $1.49 \pm 0.39$ & $56 \pm 21$ \\
\hline & Range & $16-140$ & $1.5-2.6$ & $9-1480$ & $18-151$ & $9-67$ & $1.07-2.15$ & $0.12-0.46$ & $0.73-1.46$ & $0.67-2.33$ & $1.02-2.19$ & 29-102 \\
\hline \multirow{2}{*}{$\begin{array}{l}\text { High-P } \\
\text { samples }\end{array}$} & Mean $\pm \mathrm{SD}$ & $75 \pm 36.4$ & $2.2 \pm 0.61$ & $201 \pm 167$ & $80 \pm 40$ & $33 \pm 17$ & $1.65 \pm 0.32$ & $0.22 \pm 0.06$ & $0.93 \pm 0.20$ & $1.34 \pm 0.31$ & $1.65 \pm 0.56$ & $34 \pm 18$ \\
\hline & Range & $0.4-135$ & $0.3-3.3$ & $4-540$ & $0.05-151$ & $1-67$ & $0.80-2.34$ & $0.09-0.35$ & $0.55-1.47$ & $0.88-2.38$ & $1.05-3.33$ & $12-96$ \\
\hline LSD & & 2.91 & 0.07 & 44 & 3 & 1.16 & 0.02 & 0 & 0.01 & 0.02 & 0.02 & 0.5 \\
\hline
\end{tabular}

$A$ and $b$ according to the Freundlich equation $Y=A \cdot X^{1 / b}, B C$ buffer capacity estimated from the derivate of the Freundlich equation at $\mathrm{e}=\mathrm{equilibrium}$; $0.2 \mathrm{mg} \mathrm{P} \mathrm{L}^{-1}$, and $1 \mathrm{mg} \mathrm{P} \mathrm{L}^{-1}, S D$ standard deviation, $L S D$ least significant difference $(P<0.05)$

${ }^{a}$ Significant at $P=0.0002$

${ }^{\mathrm{b}}$ Significant at $P=0.0105$

${ }^{\mathrm{c}}$ Significant at $P=0.0001$ 


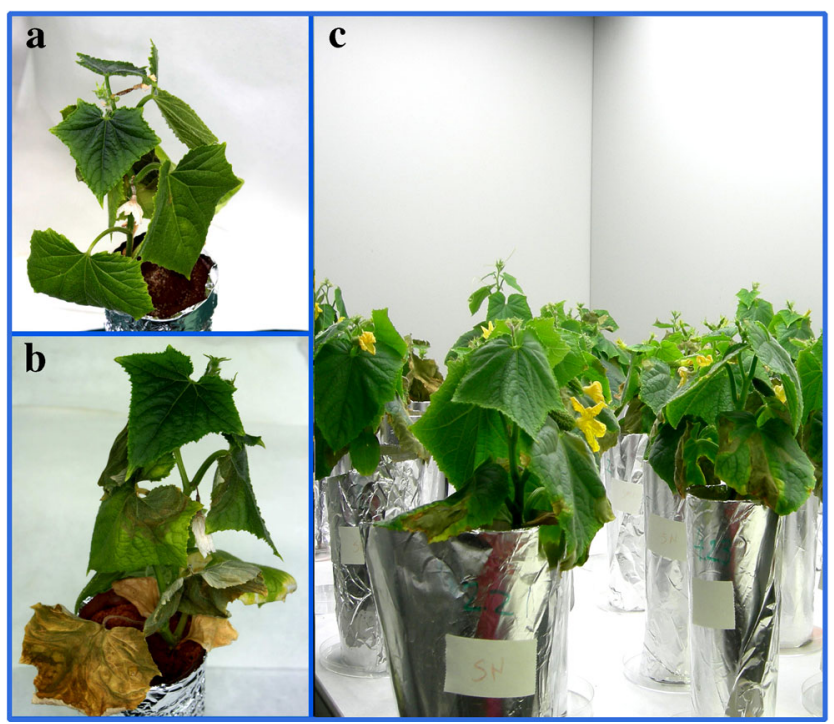

Fig. 1 Experiment with cucumber in growing chamber. a Plant after approximately 20 days after planting, without symptoms of $\mathrm{P}$ deficiency. b Clear symptoms of P deficiency in basal leaves at the end of the experiment (50 days after planting). $\mathbf{c}$ Plants in growing chamber at 30 days after planting

correlation found between this sum and $b(r=-0.5 ; P<0.05)$. Besides this, a high content in adsorbing surfaces, as those of Fe oxides (Peña and Torrent 1990), could imply a dominant role of $\mathrm{P}$ adsorption relative to $\mathrm{P}$ precipitation. In Mediterranean soils, adsorbed $\mathrm{P}$ appears to be more available than precipitated $\mathrm{P}$ in the form of insoluble metal phosphates (Delgado and Torrent 1997; Saavedra and Delgado 2005), thus contributing to explain the positive correlation between crop $\mathrm{P}$ uptake and Fe in oxides.

In contrast to high-P samples, plant $\mathrm{P}$ uptake from low-P samples related to the sum of inorganic $\mathrm{P}$ extracted by $\mathrm{NaOH}$ and cb, which explained $52 \%$ of plant P uptake (Fig. 3). This is consistent with correlations described between the sum of inorganic $\mathrm{P}$ in both fractions and the $\mathrm{P}$ availability index (Saavedra and Delgado 2005; Saavedra et al. 2007). However, in spite of these correlations, a fraction of adsorbed and precipitated $\mathrm{P}$ in these fractions cannot be considered readily available, because it likely includes $\mathrm{P}$ adsorbed on high energy sites or in metal phosphates (mainly Ca phosphates in these soils) not soluble at the usual $\mathrm{P}$ concentration in the rhizosphere (Delgado and Torrent 1997; Delgado et al. 2010). The relationship between $P$ extracted by plants and $\mathrm{NaOH}-\mathrm{P}+\mathrm{cb}-\mathrm{P}$ indicated that the inorganic $\mathrm{P}$ in these fractions that was not extracted with the Olsen reagent contributed to plant uptake in low-P pots but not in high-P pots. Mobilization of these non-bicarbonate-extractable inorganic $\mathrm{P}$ forms can be probably ascribed to organic acid exudation by roots (Jones 1998; Ström et al. 2005; Richardson et al. 2011). Extraction with cb, which is able to dissolve Ca phosphates (Saavedra and Delgado 2005), mimics to some extent the effect of the exudation of acids in rhizosphere soils buffered at basic $\mathrm{pH}$.
P uptake $\left(\right.$ mg plant $\left.^{-1}\right)$

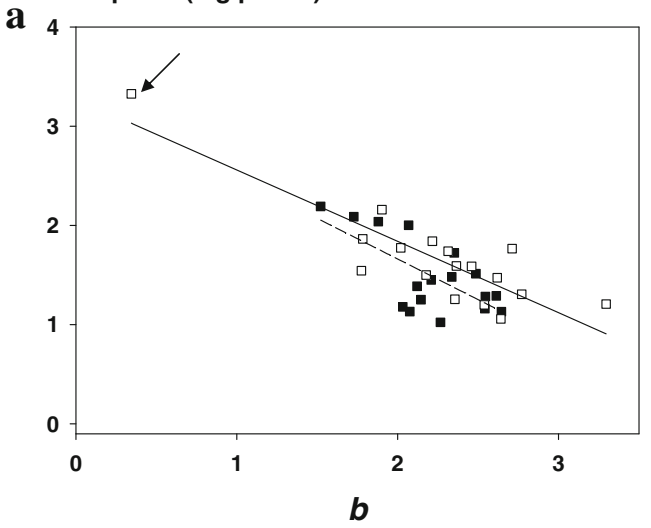

P uptake high-P (mg plant $\left.{ }^{-1}\right)$

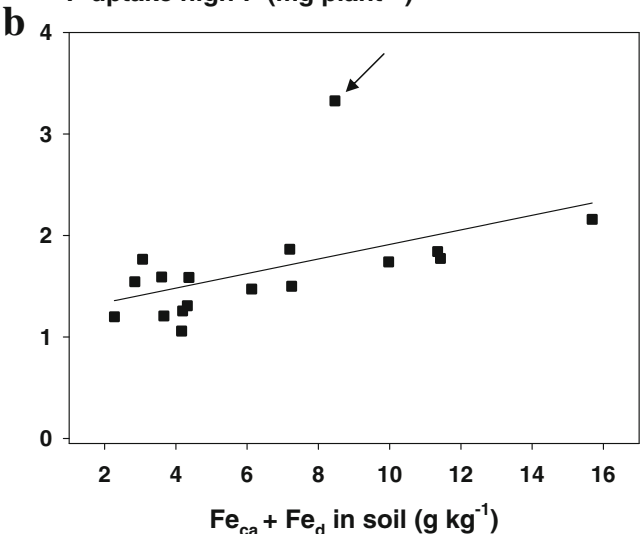

Fig. 2 a Relationship of P uptake by plants in high- (empty symbols) and low-P (solid symbols) samples with the affinity factor $(b)$ in the Freundlich equation $\left(Y=A X^{1 / b}\right) ; R^{2}=0.76, P<0.001$ for high-P samples $\left(R^{2}=0.4, P<0.01\right.$ if marked point is not included), and $R^{2}=0.46, P<0.01$ for low-P samples. b Relationship of $P$ uptake by plants in high-P samples and the sum of Fe extracted by citrate-ascorbate (ca) and citratebicarbonate-dithionite (d) [the point marked with an arrow was not included in the regression since it was clearly influential according to the Leverage test]. $R^{2}=0.57, P<0.001$. The experiment was performed with one plant per pot; in each pot the amount of Olsen $\mathrm{P}$ was the same $\left(1 \mathrm{mg} \mathrm{pot}^{-1}\right)$. Since $\mathrm{P}$ deficiency symptoms were evident in all soils, $\mathrm{P}$ uptake by the plant in each pot provides a measure of the ratio of total available $\mathrm{P}$ to Olsen $\mathrm{P}$

The phosphatase activity in the rhizosphere soil was positively correlated with the sum of organic $\mathrm{P}$ fractions present in pots with both high- and low-P samples $(r=0.75 ; P<0.001$, and $r=0.7 ; P<0.01$, respectively). This explains this activity being on average a $65 \%$ higher in pots with low-P than in those with high-P samples (Table 2) since the amount of organic $\mathrm{P}$ was much higher in the former pots. Thus, hydrolysable organic $\mathrm{P}$ can be expected to contribute to $\mathrm{P}$ uptake by plants. However, $\mathrm{P}$ extraction by plants was not correlated with the total organic $\mathrm{P}$ in the pot (as sum of OP in all the fractions) or with the phosphatase activity in the rhizospheric soil in both types of samples. When the total organic $\mathrm{P}$ in pot and phosphatase activity were considered in the model, a $37 \%$ of $\mathrm{P}$ uptake by plants growing on low-P samples was 

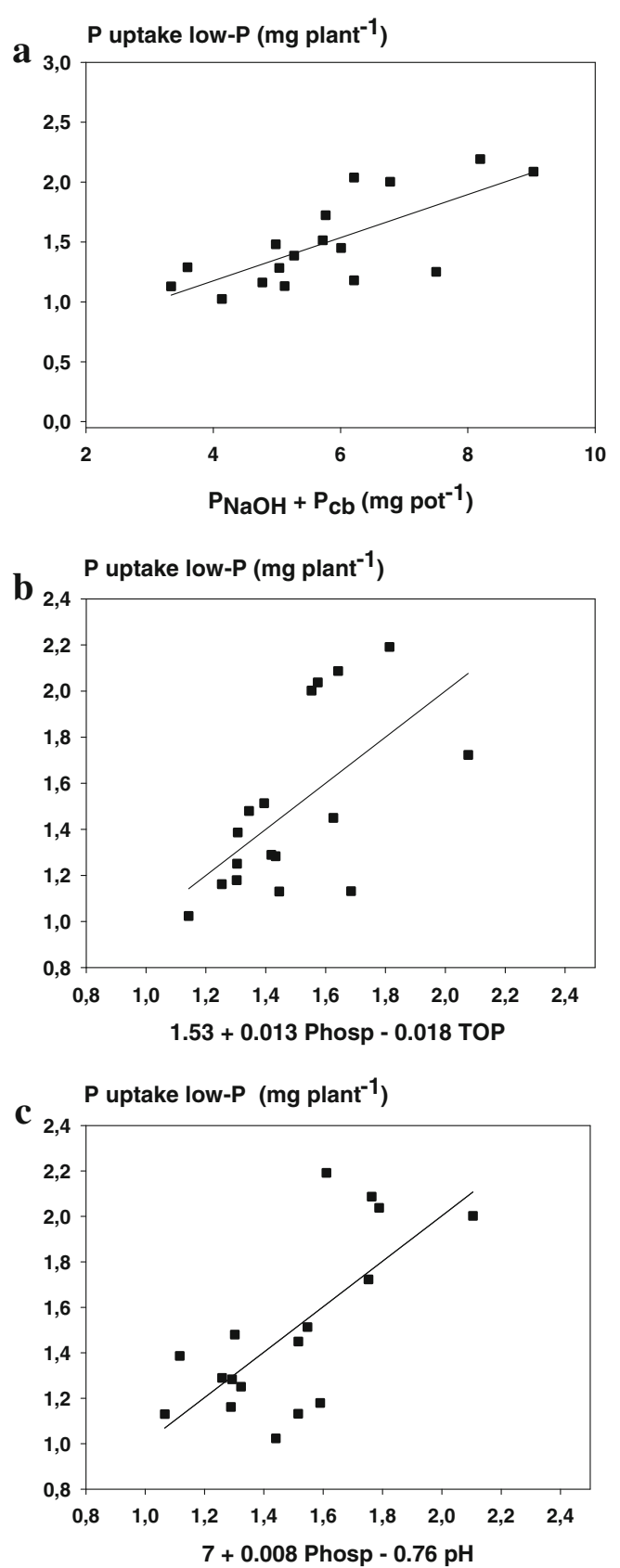

Fig. $3 \mathrm{P}$ uptake by plants in low-P samples as a function of the following. a The amount of molybdate reactive $\mathrm{P}$ (inorganic $\mathrm{P}$ ) extracted by $\mathrm{NaOH}$ and citrate-bicarbonate $(\mathrm{cb})$ in the sequential fractionation scheme $\left(R^{2}=0.52, P<0.001\right)$. b As a function of the amount of total organic P (TOP) in pots and alkaline phosphatase activity (Phosp) in the rhizosphere soil $\left(R^{2}=0.37, P<0.01\right)$. c As a function of this enzymatic activity and soil $\mathrm{pH}\left(R^{2}=0.5, P<0.001\right)$. It should be noted that the sign of multiple linear regression in (b) does not provide real information about the sense of the contribution of each independent variable since phosphatase and TOP were significantly correlated

explained (Fig. 3). Also, a linear model including phosphatase and $\mathrm{pH}$ as independent variables explained $50 \%$ of $\mathrm{P}$ extracted by plants on low-P samples (Fig. 3). This reveals that not only the total amount of organic $\mathrm{P}$ in the growing medium but also factors related to plant ability to hydrolyse these $\mathrm{P}$ forms or to affect dynamics of organic and inorganic $\mathrm{P}$ forms and hydrolytic activity $(\mathrm{pH})$ can be relevant with a view to explaining $\mathrm{P}$ uptake by plants. However, this contribution of organic forms and hydrolytic activity was evident with large amounts of organic P present in the growing media (low-P samples).

These results stress in summary that the accuracy of a soil $\mathrm{P}$ index, Olsen P in this study, is affected by: (i) the affinity of soil surfaces for P; (ii) the P forms considered non-readily available to plants such as non-readily soluble inorganic $\mathrm{P}$ or organic P forms; and (iii) root activity (acid and hydrolytic enzyme exudation). However, although these factors are known to affect the availability $\mathrm{P}$ to plants depending on particular soil conditions, an integrated view of their effects on the accurate estimation of plant-available $\mathrm{P}$ has been rarely addressed, thus explaining why they are not considered in the usual availability $\mathrm{P}$ indices. To overcome this limitation, a more accurate definition of threshold values for soil $\mathrm{P}$ indices on the basis of the aforementioned factors is required. A simple model was proposed for Olsen P by Sánchez-Alcalá et al. (2014), which was however limited since it only considered the short-term equilibrium of inorganic $\mathrm{P}$ in soil. Also, our results are of practical interest for designing new $\mathrm{P}$ indices which should rely on chemical $P$ extractions sensitive to these factors. Although P mobilization processes linked to the rhizosphere activity are widely known (Mollier et al. 2008; Hinsinger et al. 2011), our results revealed which are the targeted $\mathrm{P}$ fractions in this mobilization and under which circumstances this mobilization can contribute to plant $\mathrm{P}$ uptake (P starvation in soil). They also provided additional support for the need to consider this mobilization in models to estimate $P$ availability to plants from $P$ indices and threshold values for these indices. As mentioned above, pots with low-P samples contained much more total and organic $\mathrm{P}$ than those with high$P$ samples, but both had the same amount of readily available $\mathrm{P}$ as that estimated by Olsen P. However, results evidenced an increased use of non-readily available forms in low-P samples. This indicates a likely decreased use of inorganic $\mathrm{P}$ related to Olsen P in low-P samples when compared with high-P samples and some compensation in the $\mathrm{P}$ supply to the plant from other sources. This could reveal that not only P starvation in soil but also the ratio of non-readily available to available $\mathrm{P}$ forms in soil can determine the final contribution of nonreadily available $\mathrm{P}$ in rhizosphere to the final $\mathrm{P}$ uptake by the plant. However, the $\mathrm{P}$ extracted by plants in pots with low-P samples was even slightly lower than in those with high-P samples. All these results highlight the limitations of the accuracy of $\mathrm{P}$ availability indices. In low-P samples, mobilization of non-readily available forms did not contribute to completely overcome the nutritional consequences of a Pdeficient growing medium. In fact, in pots with low-P samples, an increased scarcity of the nutrient, in spite of the same 
theoretical amount of available $\mathrm{P}$ to plants, contributes to explain the triggering of plant root strategies to mobilize $\mathrm{P}$, such increased hydrolytic activity (Richardson et al. 2011). On the other hand, the physico-chemical factors affecting the dynamics of inorganic $\mathrm{P}$ play a crucial role in high-P samples.

\section{Conclusion}

Olsen P could not accurately predict plant P uptake from the studied soils. This uptake was explained by factors affecting the equilibrium between $\mathrm{P}$ in solid and liquid phases in high- $\mathrm{P}$ samples, mainly the affinity of soil particles for $\mathrm{P}$ and the total adsorption capacity estimated from the total $\mathrm{Fe}$ bound in $\mathrm{Fe}$ oxides. On the other hand, in pots with low-P samples, inorganic $\mathrm{P}$ released by $\mathrm{NaOH}$ and citrate/bicarbonate and the combination of total organic $\mathrm{P}$, phosphatase activity in the rhizosphere, and $\mathrm{pH}$ contributed to explain plant $\mathrm{P}$ uptake. In spite of the theoretically same amount of readily available $\mathrm{P}$ and the potential increased use of non-readily available forms (poorly soluble inorganic $\mathrm{P}$ and organic $\mathrm{P}$ ), P extracted by plants in pots with low-P samples was even slightly lower than in those with high-P samples thus suggesting that the Olsen method likely overestimates available $\mathrm{P}$ in samples with low-P status. These results are of practical interest for the correction of classical $\mathrm{P}$ availability indices by defining more accurate threshold values based on properties affecting the relationship between plant $\mathrm{P}$ uptake and $\mathrm{P}$ index values or for the design of new ones sensitive to these properties and leading thus to a more precise estimation of the soil P status.

Acknowledgments This study was funded by the Spanish Ministry of Science and Innovation and the European Regional Development Fund of the European Union through the National Research, Development and Innovation Program (Plan Nacional I+d+i, AGL2011-29893-CO2-01 and AGL2011-29893-CO2-02) and by the Regional Government of Andalucia (Project AGR 63-85). Mr. Ramiro Recena was PhD student with a grant from the Regional Government. Fertiberia S.A. and OCA Lebrija collaborated in the collection of soil samples for the present study.

\section{References}

Barrow NJ, Debnath A (2014) Effect of phosphate status on the sorption and desorption properties of some soils of northern India. Plant Soil 378:383-395. doi:10.1007/s11104-014-2042-8

Celardin F (2003) Evaluation of soil P-test values of canton Geneva/ Switzerland in relation to P loss risks. J Plant Nutr Soil Sci 166: 416-421. doi:10.1002/jpln.200321142

Colombo C, Barrón V, Torrent J (1994) Phosphate adsorption and desorption in relation to morphology and crystal properties of synthetic hematites. Geochim Cosmochim Acta 58:1261-1269

Cordell D, Neset T (2014) Phosphorus vulnerability: a qualitative framework for assessing the vulnerability of national and regional food systems to the multi-dimensional stressors of phosphorus scarcity. Global Environ Change 24:108-122. doi:10.1016/j.gloenvcha. 2013.11.005
Cordell D, Drangert J-O, White S (2009) The story of phosphorus: global food security and food for thought. Global Environ Change 19:293305

Delgado A, Scalenghe R (2008) Aspects of phosphorus transfer in Europe. J Plant Nutr Soil Sci 171:552-575. doi:10.1002/jpln. 200625052

Delgado A, Torrent J (1997) Phosphate rich soils in the European Union: estimating total plant-available phosphorus. Eur J Agron 6:205-214

Delgado A, Torrent J (2001) A comparison of soil extraction procedures for estimating the phosphorus release potential of agricultural soils. Commun Soil Sci Plant Anal 32:87-105. doi:10.1081/CSS100102995

Delgado A, del Campillo MC, Torrent J (2010) Limitations of the Olsen method to assess available phosphorus in reclaimed marsh soils. Soil Use Manage 26:133-140. doi:10.1111/j.1475-2743.2010.00264.x

Delgado A, Madrid A, Kasem S, Andreu L, del Campillo MC (2002) Phosphorus fertilizer recovery from calcareous soils amended with humic and fulvic acids. Plant Soil 245:277-286

Díaz-Espejo A, Serrano L, Toja J (1999) Changes in sediment phosphate composition of seasonal ponds during filling. Hydrobiologia 392: 21-28. doi:10.1023/A:1003557408640

Ehlert P, Morel C, Fotyma M, Destain JP (2003) Potential role of phosphate buffering capacity of soils in fertilizer management strategies fitted to environmental goals. J Plant Nutr Soil Sci 166:409-415

Fox RL, Kamprath EJ (1970) Phosphate sorption isotherms for evaluating the phosphate requirements of soils. Soil Sci Soc Am Proc 34:902-907

Gee GW, Bauder JW (1986) Particle-size analysis. In Klute A (ed) Methods of soil analysis. Part 1. 2nd ed. Agron. Monogr. 9. ASA and SSSA, Madison, WI pp 383-411

Golterman HL, Paing J, Serrano L, Gómez E (1998) Presence of and phosphate release from polyphosphates or phytate phosphate in lake sediments. Hydrobiologia 364:99-104. doi:10.1023/ A:1003212908511

Guzman G, Alcántara E, Barrón V, Torrent J (1994) Phytoavailability of phosphate adsorbed on ferrihydrite, hematite, and goethite. Plant Soil 159:219-225

Hinsinger P, Brauman A, Devau N, Gérard F, Jourdan C, Laclau JP, Le Cadre E, Jaillard B, Plassard C (2011) Acquisition of phosphorus and other poorly mobile nutrients by roots. Where do plant nutrition models fail? Plant Soil 348(1-2):29-61. doi:10.1007/s11104-0110903-y

Holford ICR (1980) Effects of phosphate buffer capacity on critical levels and relationships between soil tests and labile phosphate in wheat growing soils. Aust J Soil Res 18:405-414

Jones DL (1998) Organic acids in the rhizosphere -a critical review. Plant Soil 205:25-44

Keyzer M (2010) Towards a closed phosphorus cycle. DE Economist $158: 411-425$

Kpomblekou K, Tabatabai MA (1997) Effect of cropping systems on quantity/intensity relationships of soil phosphorus. Soil Science 162:56-68

Kulhánek M, Balík J, Černý J, Nedvědv KB (2007) The influence of different intensities of phosphorus fertilizing on available phosphorus contents in soils and uptake by plants. Plant Soil Environ 53: $382-387$

Mallarino AP (1997) Interpretation of soil phosphorus test for corn in soils with varying $\mathrm{pH}$ and calcium carbonate content. J Prod Agric 10:163-167

Mason S, McNeill A, McLaughlin MJ, Zhang H (2010) Prediction of wheat response to an application of phosphorus under field conditions using diffusive gradients in thin-films (DGT) and extraction methods. Plant Soil 337:243-258

McDowell R, Sharpley A, Withers P (2002) Indicator to predict the movement of phosphorus from soil to subsurface flow. Environ Sci Technol 36:1505-1509 
Mollier A, De Willigen P, Heinen M, Morel C, Schneider A, Pellerin S (2008) A two dimensional model of phosphorus uptake including crop growth and P-response. Ecol Model 210:453-464. doi:10. 1016/j.ecolmodel.2007.08.008

Murphy J, Riley JP (1962) A modified single solution method for the determination of phosphate in natural waters. Anal Chim Acta 27: $31-36$

Neyroud JA, Lischer P (2003) Do different methods used to estimate soil phosphorus availability across Europe give comparable results? J Plant Nutr Soil Sci 166:422-431

Olsen SR, Cole CV, Watanabe FS, Dean LA (1954) Estimation of available phosphorus in soils by extraction with sodium bicarbonate. USDA Circular 939. US Government Printing Office, Washington DC

Peña F, Torrent J (1990) Predicting phosphate sorption in soils of Mediterranean regions. Fert Res 23:173-179. doi:10.1007/ BF01073433

Richardson AE, Lynch JP, Ryan PR, Delhaize E, Smith FA, Smith SE, Harvey PR, Ryan MH, Veneklaas EJ, Lambers H, Oberson A, Culvenor RA, Simpson RJ (2011) Plant and microbial strategies to improve the phosphorus efficiency of agriculture. Plant Soil 349: 121-156. doi:10.1007/s11104-011-0950-4

Ruiz JM, Delgado A, Torrent J (1997) Iron-related phosphorus in overfertilized European soils. J Environ Qual 26:1548-1554. doi: 10.2134/jeq1997.00472425002600060014x

Ryan J, Ibrikci H, Delgado A, Torrent J, Sommer R, Rashid A (2012) Significance of phosphorus for agriculture and the environment in the West Asia and North Africa region. Adv Agron 114:91-153. doi: 10.1016/B978-0-12-394275-3.00004-3

Saavedra C, Delgado A (2005) Phosphorus fractions and release patterns in typical Mediterranean soils. Soil Sci Soc Am J 69:607-615. doi: $10.2136 /$ sssaj2004.0156

Saavedra C, Velasco J, Pajuelo P, Perea F, Delgado A (2007) Effects of tillage on phosphorus release potential in a Spanish Vertisol. Soil Sci Soc Am J 71:56-63. doi:10.2136/sssaj2006.0162
Sánchez-Alcalá I, del Campillo MC, Barrón V, Torrent J (2014) The Olsen P/solution P relationship as affected by soil properties. Soil Use Manage 30:454-462. doi:10.1111/sum.12141

Soil Survey Staff (2010) Keys to soil taxonomy, 11 th edn. USDA-Natural Resources Conservation Service, Washington, DC

Ström L, Owen AG, Godbold DL, Jones DL (2005) Organic acid behaviour in a calcareous soil implications for rhizosphere nutrient cycling. Soil Biol Biochem 37:2046-2054

Sumner ME, Miller WP (1996) Cation exchange capacity and exchange coefficients. In: Bigham J (ed) Methods of soil analysis: part 3, Chemical methods. Soil Science Society of America, Madison, pp 1201-1229

Tabatabai MA (1994) Soil enzymes. In Bigham JM (ed) Methods of soils analysis. Part 2- Microbiological and biochemical properties. Soil Science Society of America Book series number 5, Madison, WI, pp $775-833$

Tandy S, Mundus S, Yngvesson J, de Bang TC, Lombi E, Schjoerring JK, Husted S (2011) The use of DGT for prediction of plant available copper, zinc and phosphorus in agricultural soils. Plant Soil 346: 167-180. doi:10.1007/s11104-011-0806-y

Tóth G, Guicharnaud RA, Tóth B, Hermann T (2014) Phosphorus levels in croplands of the European Union withimplications for P fertilizer use. Eur J Agron 55:42-52. doi:10.1016/j.eja.2013. 12.008

Van Vuuren DP, Bouwman AF, Beusen AHW (2010) Phosphorus demand for the 1970-2100 period: a scenario analysis of resource depletion. Global Environ Change 20:428-439

Walkley A, Black IA (1934) An examination of the Degtjareff method for determining organic carbon in soils: Effect of variations in digestion conditions and of inorganic soil constituents. Soil Sci 63:251-263

Withers PJA, Neal C, Jarvie HP, Doody DG (2014) Agriculture and eutrophication: where do we go from here? Sustainability 6:58535875. doi:10.3390/su6095853 